\title{
Evaluation of Small-Bowel Patency in Crohn's Disease: Prospective Study with a Patency Capsule and Computed Tomography
}

\author{
Marco Silva ${ }^{a}$ Hélder Cardoso $^{a}$ Rui Cunhab Armando Peixoto $^{a}$ Rui Gaspar ${ }^{a}$ \\ Sara Gomes ${ }^{c}$ Ana Luísa Santos ${ }^{a}$ Susana Lopes ${ }^{a}$ Guilherme Macedo ${ }^{a}$

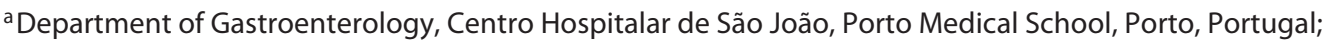 \\ ${ }^{b}$ Department of Imagiology, Centro Hospitalar de São João, Porto Medical School, Porto, Portugal; ' Department of \\ General Practice, UCSP Rio Maior, ACES Lezíria, Rio Maior, Portugal
}

\section{Keywords}

Inflammatory bowel disease $\cdot$ Diagnosis and imaging · Small-bowel endoscopy - Capsule endoscopy · Gastrointestinal radiology

\section{Abstract}

Background and Purpose: Patency capsule (PC) examination is usually performed - previously to capsule endoscopy - to evaluate small-bowel patency in patients with established Crohn's disease (CD). The reported PC retention rate is significantly higher than expected. Our aims were to assess small-bowel patency, to determine the precise location of the retained $P C$ in patients with $C D$, and to determine the false positive rate of evaluation with a radiofrequency identification tag (RFIT) scanner. Methods: This is a prospective single-center study including CD patients with clinical indication for small-bowel capsule endoscopy. PillCam ${ }^{\circledR}$ PC examination was performed on all patients to assess smallbowel patency. On all patients with a positive identification of the PC using an RFIT scanner, $30 \mathrm{~h}$ after ingestion, an abdominal CT was performed in order to identify its precise location. Results: Fifty-four patients were included. The PC retention rate, according to evaluation with the RFIT scanner, was $20 \%$ (in 11 patients) $30 \mathrm{~h}$ after ingestion. These patients were then submitted to abdominal $\mathrm{CT}$, which revealed that there was small-bowel retention in 5 cases (9\%). Higher CRP levels, penetrating disease, and a history of abdominal surgery were associated with an increased risk of PC retention ( $p=0.007, p=0.011$, and $p=0.033$, respectively). On multivariate analysis, there was an independent association between small-bowel PC retention and CRP levels $>5 \mathrm{mg} / \mathrm{dL}$ $(\mathrm{OR}=15.5 ; p=0.03)$. Discussion: The small-bowel PC retention rate (9\%) was considerably lower than those found in previous reports. Our results show that, with this protocol, the false-positive cases of RFIT scans or plain abdominal Xrays may be avoided. This may contribute to more extensive application of capsule endoscopy without the risk of smallbowel retention.

(c) 2019 Sociedade Portuguesa de Gastrenterologia Published by S. Karger AG, Basel

\section{Avaliação da patência do intestino delgado na doença de Crohn: estudo prospetivo com cápsula de patência e tomografia computadorizada}

\section{Palavras Chave}

Doença inflamatória intestinal · Diagnóstico e imagem - Endoscopia do intestino delgado - Endoscopia por cápsula $\cdot$ Imagiologia gastrointestinal

\section{KARGER}

E-Mail karger@karger.com www.karger.com/pjg
(C) 2019 Sociedade Portuguesa de Gastrenterologia Published by S. Karger AG, Basel

Karcer

Open access

This article is licensed under the Creative Commons AttributionNonCommercial-NoDerivatives 4.0 International License (CC BYNC-ND) (http://www.karger.com/Services/OpenAccessLicense). Usage and distribution for commercial purposes as well as any distribution of modified material requires written permission.
Marco Silva

Department of Gastroenterology, Centro Hospitalar de São João

Alameda Professor Hernâni Monteiro

PT-4200-319 Porto (Portugal)

E-Mail marcocostasilva87@gmail.com 


\section{Resumo}

Introdução: A cápsula de patência (CP) é geralmente realizada para avaliar a patência do intestino delgado, previamente à realização de cápsula endoscópica (VCE), em doentes com doença de Crohn (DC) diagnosticada. Notavelmente, a taxa de retenção da CP nos doentes com DC é significativamente superior à taxa global de retenção de VCE. Os autores pretendem avaliar a patência do intestino delgado e determinar a localização precisa das CP retidas nos doentes com DC, determinar a taxa de falsos positivos da avaliação com RFIT scanner, bem como avaliar possíveis fatores associados. Métodos: Estudo prospetivo de um centro único, incluindo doentes com DC com indicação clínica para VCE. A PillCam ${ }^{\circledR}$ CP foi realizada em todos os doentes para avaliar a patência do intestino delgado. Nos doentes com deteção positiva da CP através de um radiofrequency identification tag (RFID) scanner, 30 horas após a ingestãofoi realizada uma tomografia computadorizada abdominal (TC) de forma a determinar a localização precisa da cápsula. Resultados: Foram incluídos 54 doentes. A taxa de retenção da CP 30h, na avaliação com RFIT scanner, após a ingestão foi de $20 \%$ (11). Estes doentes foram então submetidos a TC abdominal, que detetou a CP no intestino delgado apenas em 5 (9\%) doentes. Níveis mais elevados de PCR, doença penetrante e história de cirurgia abdominal foram associados com aumento do risco de retenção da $C P(p=0,007, p=0,011$ e $p=0,033$, respetivamente). $\mathrm{Na}$ análise multivariada, houve uma associação independente entre retenção da cápsula do intestino delgado e níveis de $\mathrm{PCR}>5 \mathrm{mg} / \mathrm{dL}(\mathrm{OR}=15,5 ; p=$ $0,03)$. Conclusões: $A$ taxa de retenção da $C P$ no intestino delgado ( $9 \%$ ) foi consideravelmente menor do que a previamente reportada. Estes resultados mostram que, com este protocolo, os casos falso positivos do RFIT scanner ou radiografia abdominal simples podem ser evitados. Isso pode contribuir para uma aplicação mais extensa da VCE sem o risco de retenção do intestino delgado.

(c) 2019 Sociedade Portuguesa de Gastrenterologia Publicado por S. Karger AG, Basel

\section{Introduction}

The development of wireless video capsule endoscopy (CE) has been widely considered to be a breakthrough for endoluminal visualization of the entire small bowel [1]. The most significant complication is capsule retention, although the rate of this specific risk varies depending on the clinical indication for CE [2]. Crohn's disease (CD) is associated with an increased risk of capsule endoscope retention (up to $13 \%$ in some studies) $[3,4]$.

Evaluation of Small-Bowel Patency in Crohn's Disease
The patency capsule (PC) was developed to provide evidence of functional patency of the gut lumen in CD patients, in order to avoid capsule endoscope retention [5-7]. When the PC is not excreted intact, or if pain is experienced during its passage, $\mathrm{CE}$ would not be a safe procedure [5]. If the $\mathrm{PC}$ has passed the intestinal tract within $30 \mathrm{~h}$, capsule endoscope retention is most unlikely [8].

Notably, the reported PC retention rate is significantly higher than the expected capsule endoscope retention rate for $\mathrm{CD}$ patients, having been up to $28 \%$ in previous studies [3]. This difference may be related to delayed bowel transit time. Thus, considering the highly variable bowel transit times, the cutoff of $30 \mathrm{~h}$ can easily be exceeded in healthy subjects, precluding the assessment of bowel patency and subsequent CE.

When the PC is not excreted within the defined time frame, an abdominal radiography is usually performed to determine the PC's location; however, it is often impossible to detect with certainty whether the PC is in the large or in the small bowel. Other tests (e.g., CT) have been used to confirm the PC's location [9].

Our aims were to assess small-bowel patency, to determine the precise location of the retained PC in patients with established $\mathrm{CD}$, and to determine the false positive rate of evaluation with a radiofrequency identification tag (RFIT) scanner.

\section{Methods}

We designed a prospective single-center study. All consecutive patients with established CD and a clinical indication for CE between December 2015 and February 2017 were enrolled in the study.

PillCam PC (GIVEN Imaging, Yokneam, Israel) examination was performed on all patients to assess small-bowel patency. The PillCam PC is a device $26 \mathrm{~mm}$ long and $11 \mathrm{~mm}$ wide composed of lactose and 5\% barium sulfate [3]. It has a small inner RFIT that allows scanner identification, and two timer plugs that seal the capsule's body [3]. After $30 \mathrm{~h}$ in the digestive system, the PC begins to disintegrate, even when the device is blocked in a stricture [3].

In our study, after a 12 -h fasting period, the PC was ingested without previous bowel preparation. Eating and drinking were started $4 \mathrm{~h}$ after the ingestion of the capsule, and the patients were allowed to continue their usual daily life.

RFIT scanner detection was performed and symptoms were assessed $30 \mathrm{~h}$ after PC ingestion. On patients with a positive PC identification, an abdominal CT was performed within $1 \mathrm{~h}$. CT images were acquired using a 64-slice multidetector CT scanner (Somatom Sensation 64 CT Scanner; Siemens AG, Erlangen, Germany), with a reconstruction slice thickness of $5 \mathrm{~mm}$ and a slice interval of $0.5 \mathrm{~mm}$. In order to minimize radiation exposure, a range of images around (above and below) the PC were acquired, based 
on a scout view. The effective radiographic exposure dose was estimated by multiplying the dose length product given by the CT scanner by a region-specific coefficient of 0.015 based on international recommendations [7].

The gastrointestinal tract was considered patent (without PC retention) if the capsule was excreted intact, or if the capsule was not detected by the scanner $30 \mathrm{~h}$ after ingestion. Also patients with $\mathrm{PC}$ retention in the colon, detected by abdominal CT, were considered to have small-bowel patency. All of these patients were afterwards submitted to CE. When the retained PC was located in the small bowel on abdominal CT, the small bowel was considered not to be patent. These patients did not undergo CE.

Statistical analysis was performed with version 22 of the SPSS ${ }^{\circledR}$ software (SPSS Inc., Chicago, IL, USA). A $p$ value $<0.05$ was considered significant. Data were analyzed using the $\chi^{2}$ test for categorical variables, the independent-samples $t$ test and the MannWhitney U nonparametric test for continuous variables, and logistic regression for multivariate analysis.

\section{Results}

During the period of the study, 54 consecutive patients with a previous diagnosis of CD were included. The majority $(65 \%)$ of the patients were female, and the mean age was $40.5 \pm 11.1$ years. The median time since CD diagnosis until PC examination was 46 months (IQR 10-111) (Table 1). Regarding the CD classification (Montreal classification), most of the patients had been diagnosed between 17 and 40 years of age (A2 $=59 \%)$, had nonstricturing, nonpenetrating disease behavior $(\mathrm{B} 1=76 \%)$, and had an ileal location of the disease $(\mathrm{L} 1=63 \%)$. There was perianal involvement in $13 \%$ of the cases.

The clinical indications for $\mathrm{CE}$ were $\mathrm{CD}$ staging due to unexplained symptoms or assessment of therapeutic efficacy in 49 patients (91\%), and persistent anemia despite optimized medical therapy in the remaining 5 cases (9\%).

All patients had previously undergone an ileocolonoscopy and $78 \%$ had had at least one previous abdominal imaging (enterography by CT or magnetic resonance). Twelve (22\%) of the patients had a known or suspected small-bowel stenosis detected by previous ileocolonoscopy or abdominal imaging; 5 of them had a distal ileal stenosis, or a stenosis of the ileocecal valve, and 7 had an ileal stenosis detected only on abdominal imaging. Twelve $(22 \%)$ of the patients had a history of abdominal surgery (intestinal resection, $n=7$ ).

The PC retention rate was $20 \%$ (in 11 patients) $30 \mathrm{~h}$ after ingestion. These patients were then submitted to abdominal CT, which revealed that there was small-bowel $\mathrm{PC}$ retention in 5 cases (9\%), while in the remaining patients the PC was already in the colon. CT located the PC in the proximal jejunum in 1 case, in the proximal ileum
Table 1. Demographic and clinical data on the CD patients $(n=$ 54) submitted to PC examination

\begin{tabular}{lc}
\hline Parameter & Value \\
\hline Gender & \\
Female, $n(\%)$ & $35(65)$ \\
Male, $n(\%)$ & $19(35)$ \\
Mean age \pm SD, years & $40.5 \pm 11.1$ \\
Median CD diagnosis time until PC & \\
$\quad$ examination (IQR), months & $45.5(9.8-111.5)$ \\
Montreal classification CD, $n(\%)$ & \\
Age group & \\
A1 & $1(1.9)$ \\
$\quad$ A2 & $32(59.3)$ \\
A3 & $21(38.8)$ \\
CD location & $34(63.0)$ \\
L1 & $3(5.5)$ \\
L2 & $17(31.5)$ \\
L3 & $5(9.3)$ \\
$\quad(+)$ L4 & \\
CD behavior & $41(75.9)$ \\
B1 & $5(9.3)$ \\
B2 & $8(14.8)$ \\
B3 & $7(13)$ \\
Perianal involvement, $n(\%)$ & $12(22.2)$ \\
Previous abdominal surgery, $n(\%)$ & $13.4 \pm 1.9$ \\
Mean hemoglobin \pm SD, g/dL & $43.0 \pm 3.4$ \\
Mean albumin \pm SD, g/L $(1.9(0.8-4.3)$ \\
Median C-reactive protein $(\mathrm{IQR}), \mathrm{mg} / \mathrm{L}$ & $1.45 \pm 0.55$ \\
Mean radiographic exposure \pm SD, mSv & \\
\hline
\end{tabular}

$\mathrm{CD}$, Crohn's disease; PC, patency capsule.

in 1 case, and in the distal ileum/immediately proximal to the ileocolic anastomosis in the other 3 cases. Two patients (4\%) presented with symptomatic PC retention and 1 patient (2\%) was admitted due to self-limited smallbowel obstruction.

All 49 patients with confirmed small-bowel patency underwent CE up to 1 month after the PC test, without adverse events. In 2 cases (5\%) the capsule endoscope did not reach the cecum until the end of the recorder's battery life. These patients had previously had a normal PC examination. One of these patients had evidence of a distal ileal stenosis on the previous abdominal CT enterography image. In both patients, CE did not show any stricture, and abdominal radiography was used to confirm excretion of the capsule up to 1 week later.

Of the 5 patients without intestinal patency, 2 patients with proximal retention of the PC underwent CT enterography, which showed ileal stenosis and fistulizing disease in one of the cases and no alterations in the other 
Table 2. Comparison between patients with and those without gastrointestinal patency

\begin{tabular}{|c|c|c|c|}
\hline Variable & Patent $(n=49)$ & Nonpatent $(n=5)$ & $p$ value \\
\hline Gender, $n(\%)$ & & & $0.223^{\mathrm{a}}$ \\
\hline Male & $16(84.2)$ & $3(15.8)$ & \\
\hline Female & $33(94.3)$ & $2(5.7)$ & \\
\hline Mean age at $\mathrm{PC}$ examination $\pm \mathrm{SD}$, years & $40.0 \pm 11.5$ & $45.2 \pm 4.4$ & $0.082^{\mathrm{b}}$ \\
\hline Median time from CD diagnosis until PC & & & \\
\hline examination (IQR), years & $4.5(0.9-9.6)$ & $1.0(0-3.0)$ & $0.166^{\mathrm{c}}$ \\
\hline \multicolumn{4}{|l|}{ Montreal classification CD, $n(\%)$} \\
\hline Age group & & & $0.112^{\mathrm{a}}$ \\
\hline A1 & $1(100)$ & 0 & \\
\hline $\mathrm{A} 2$ & $32(97.0)$ & $1(3.0)$ & \\
\hline A3 & $16(80.0)$ & $4(20.0)$ & \\
\hline CD location & & & $0.198^{\mathrm{a}}$ \\
\hline L1 & $29(85.3)$ & $5(14.7)$ & \\
\hline $\mathrm{L} 2$ & $3(100)$ & 0 & \\
\hline L3 & $17(100)$ & 0 & \\
\hline$(+) \mathrm{L} 4$ & $5(100)$ & 0 & $0.448^{\mathrm{a}}$ \\
\hline CD behavior & & & $0.011^{\mathrm{a}}$ \\
\hline B1 & $39(95.1)$ & $2(4.9)$ & \\
\hline $\mathrm{B} 2$ & $5(100)$ & 0 & \\
\hline B3 & $5(62.5)$ & $3(37.5)$ & \\
\hline History of small-bowel stenosis, $n(\%)$ & & & $0.330^{\mathrm{a}}$ \\
\hline Yes & $10(83.3)$ & $2(16.7)$ & \\
\hline No & $39(92.9)$ & $3(7.1)$ & \\
\hline Previous abdominal surgery, $n(\%)$ & & & $\mathbf{0 . 0 3 3 ^ { \mathrm { a } }}$ \\
\hline Yes & $9(75.0)$ & $3(25.0)$ & \\
\hline No & $40(95.2)$ & $2(4.8)$ & \\
\hline Mean hemoglobin $\pm \mathrm{SD}, \mathrm{g} / \mathrm{dL}$ & $13.3 \pm 1.9$ & $13.7 \pm 0.9$ & $0.146^{\mathrm{b}}$ \\
\hline Mean albumin $\pm \mathrm{SD}, \mathrm{g} / \mathrm{L}$ & $43.4 \pm 3.1$ & $39.7 \pm 4.9$ & $0.076^{\mathrm{b}}$ \\
\hline Median C-reactive protein level (IQR), mg/L & $1.6(0.8-4.1)$ & $5.8(2.9-23.6)$ & $0.007^{\mathrm{c}}$ \\
\hline
\end{tabular}

Bold type indicates significance. CD, Crohn's disease; PC, patency capsule. ${ }^{a} \chi^{2}$ test. ${ }^{b}$ Independent-samples $t$ test. ${ }^{\mathrm{c}}$ Mann-Whitney U nonparametric test.

Table 3. Variables independently associated with a nonpatent small bowel in CD patients, using logistic regression

\begin{tabular}{lrll}
\hline Variable & OR & $95 \% \mathrm{CI}$ & $p$ value \\
\hline C-reactive protein level $>5 \mathrm{mg} / \mathrm{dL}$ & 15.5 & $1.3-183.3$ & $\mathbf{0 . 0 3}$ \\
Previous abdominal surgery & 2.8 & $0.2-43.0$ & 0.460 \\
Penetrating phenotype & 4.5 & $0.3-69.0$ & 0.283 \\
\hline
\end{tabular}

Bold type indicates significance. $\mathrm{CD}$, Crohn's disease.

case. The 3 patients with distal retention of the PC underwent ileocolonoscopy, which showed an ulcerated stenosis of the terminal ileum in 1 case, a fibrotic stenosis of the ileocecal valve in 1 case, and an anastomotic stenosis in 1 case.

Evaluation of Small-Bowel Patency in Crohn's Disease
The patients with small-bowel PC retention had higher CRP levels than the patients without PC retention (5.8 vs. $1.6 \mathrm{mg} / \mathrm{dL} ; p=0.007$ ) (Table 2). Also, penetrating disease and a history of abdominal surgery were associated with an increased risk of PC retention ( $p=0.011$ and $p=$ 0.033 , respectively). On multivariate analysis, there was an independent association between small-bowel PC retention and CRP levels $>5 \mathrm{mg} / \mathrm{dL}(\mathrm{OR}=15.5 ; p=0.03)$ (Table 3).

\section{Discussion}

CE allows excellent visualization of the small-bowel mucosa, and is the procedure of choice for evaluating obscure bleeding, small-bowel tumors, and inflammation $[1,10]$. CE is superior to radiographic procedures in de- 
tecting inflammation of the small bowel, and thus, CD is among the main indications for this procedure, since in nearly $30 \%$ of CD patients, inflammation is limited to the small bowel $[1,11]$. In addition to its use for establishing the diagnosis, CE is also an essential examination technique for monitoring CD activity, determining treatment strategies, and detecting complications, because lesions in the small-bowel mucosa can be observed using this minimally invasive technique $[10,12]$.

However, capsule retention is one of the most severe complications of this examination technique [9]. Capsule retention has been defined as having the video capsule remaining in the digestive tract for a minimum of 2 weeks or requiring direct medical, endoscopic, or surgical intervention for removal [13]. The main risk factor for capsule endoscope retention is known or suspected $\mathrm{CD}$, with a risk of up to $13 \%$ in some studies [12]. In patients with symptomatic small-bowel obstruction, the risk increases to over $16 \%$ [8]. Further risk factors for capsule retention include small-bowel tumor, nonsteroidal anti-inflammatory drug enteropathy, previous abdominal surgery, intestinal ischemia, volvulus, umbilical hernia, and radiation enteritis (history of abdominal or pelvic radiotherapy) [13-15].

The PC is a nonendoscopic capsule of the same shape and dimensions as the video capsule and was developed to assess the patency of the gastrointestinal tract in order to avoid capsule endoscope retention [12]. Nowadays, CE may be performed even on patients with an increased risk of capsule retention, since it is considered safe to perform $\mathrm{CE}$ following the successful excretion of the PC $30 \mathrm{~h}$ after its ingestion $[8,9]$. On the other hand, CE cannot be recommended as a safe procedure for patients with a nonpatent small bowel on PC examination, or if pain is experienced during its passage [5].

Previous studies have shown that the sensitivity of the PC in detecting a small-bowel stenosis is comparable to that of other diagnostic tools such as barium small-bowel follow-through, CT, or magnetic resonance imaging in patients with risk factors for capsule retention [14]. One retrospective study compared the performance of the PC and radiological examinations to detect clinically significant small-bowel strictures, and both methods appear to be equivalent [16], even though other studies reported higher false positive rates with radiological examinations $[15,17]$. Radiological tests have some limitations compared with the PC: they can also produce false-negative results, especially when strictures are of short extension or the obstruction is intermittent or partial [18].
The current European Crohn's and Colitis Organisation (ECCO) guidelines recommend the exclusion of significant intestinal stenosis using the PC or radiological imaging only on patients with documented CD but not in the case of suspected CD before CE examination [11]. However, the new Japanese Guidelines [19] recommend that the gastrointestinal patency test with a PC should be done before $\mathrm{CE}$ in all cases with suspected $\mathrm{CD}$, due to the high risk of capsule endoscope retention.

The total transit time in the gastrointestinal tract varies depending on the patient's general health condition, age, gender, liquid ingestion, and food consistency [8]. The gastric passage time varies from almost instantly to as much as $6 \mathrm{~h}$ [8]. Passage through the small intestine usually takes about 5-7 h [20]. Finally, the colon transit time may range from 12 to $48 \mathrm{~h}$, although in rare cases it can reach up to $80 \mathrm{~h}$ [20]. Considering these highly variable physiological transit times, the cutoff of $30 \mathrm{~h}$ after ingestion related to capsule integrity may be exceeded in healthy subjects, and this factor may limit CE use in clinical practice. In fact, the delayed bowel transit time may justify the difference between expected CE and PC retention rates in CD patients (up to $13 \%$ and up to $28 \%$, respectively) [4-6].

If a PC is not excreted from the patient's body within the defined period, radiography is usually performed to determine its location [11]. Recently, Omori et al. [21] reported a low negative predictive value of plain X-ray for determining the accurate PC location, because it is often difficult to radiographically detect whether the PC is in the large or in the small intestine. This limitation is presumably related to abdominal anatomy, with the small and large intestines being packed together in the peritoneal space, and X-ray not providing sufficient information about soft tissues [21]. In this context, other tests such as gastrointestinal tomography (fluoroscopic tomography) and CT are often needed to confirm PC location $[17,22]$. However, the exposure to ionizing radiation with these techniques is a concern that should be taken into account [17]. Generally, the radiation exposure from plain abdominal X-ray is relatively limited (approx. 1 $\mathrm{mSv}$ ), but for those requiring further imaging such as fluoroscopy or limited abdominal CT, the dose is between 2 and $4 \mathrm{mSv}$ [17]. In order to minimize exposure to radiation, in this study, the photographed area was reduced to around the PC based on a scout view. Overall, the mean actual radiographic dose in the 11 patients who underwent CT was $1.45 \pm 0.55 \mathrm{mSv}$. In the study by Shirasawa et al. [9], a low-dose CT (LDCT) scanner was used instead of a conventional CT scanner, reducing radiation expo-
Silva/Cardoso/Cunha/Peixoto/Gaspar/ Gomes/Santos/Lopes/Macedo 
sure to levels below those from abdominal X-ray. The use of a "conventional" CT scanner is a limitation of our study. In fact, recently, our institution has acquired an LDCT scanner, but it was not available at the time of study enrollment. The use of LDCT scanners may facilitate the wider use of this strategy.

In our study, the use of an RFIT scanner made initial plain abdominal X-ray redundant in $43 / 54$ (80\%) of the patients in whom PC transit was complete, reinforcing the utility of this simple noninvasive technique for initial assessment, as previously suggested [17]. Our small-bowel patency rate $(80 \%)$ was similar to the rates reported in other series, such as those by Albuquerque et al. [3] (72\%), Boivin et al. [5] (73\%), Yoshimura et al. [23] (73\%), and Signorelli et al. [6] (81\%).

Abdominal CT was performed in 11 cases (20\%), confirming true small-bowel retention in 5 patients (9\%), which is similar to the expected capsule endoscope retention rate previously reported for CD patients [4]. Notably, this rate is significantly lower than the reported PC retention rate in $C D$ patients, as stated above $[3,5,6]$. In fact, these results highlight one of the limitations of PC examination: the false-positive results that can occur when the RFIT is in the colon rather than the small bowel, thereby precluding CE [16]. In the work of Sawada et al. [24], including patients with suspected or confirmed CD, 57 patients with suspected PC retention in the small bowel on $\mathrm{X}$-ray examination underwent abdominal CT, which confirmed true small-bowel retention in 12 cases (decreasing the global PC retention rate from 25.5 to $9.5 \%$ ). We agree with the strategy defended by Postgate et al. [17], since the additional screening is worthwhile as the majority of PCs could be located in the colon and these patients remain suitable for CE. Also, Mitselos et al. [25] have recently proposed an algorithm for the evaluation of intestinal patency, similar to our protocol, suggesting the performance of X-ray tomography or limited CT scanning in case of $\mathrm{PC}$ retention $30 \mathrm{~h}$ after ingestion in order to mitigate the occurrence of false-positive cases of PC.

A penetrating $\mathrm{CD}$ phenotype, a history of abdominal surgery, and elevated CRP levels were associated with a higher risk of PC retention $(p=0.011, p=0.033$, and $p=$ 0.017 , respectively) on univariate analysis. This is in accordance with previous reports that highlight previous abdominal surgery as one of the risk factors for capsule retention [14, 15]. Also, these results are in accordance with the previous reports by Albuquerque et al. [3] and Jürgens et al. [26], since a penetrating CD phenotype is strongly associated with concomitant intestinal strictures [16]. In fact, fistulas are thought to develop in regions of full-thickness bowel wall inflammation in a high-pressure region upstream from a stricture $[25,26]$.

However, in multivariate analysis, only CRP levels $>5$ $\mathrm{mg} / \mathrm{dL}(\mathrm{OR}=15.5 ; p=0.03)$ was independently associated with negative small-bowel patency, using logistic regression. CRP is no specific biomarker of CD, since it reflects generalized inflammation, and its levels are also increased with various viral and bacterial infections, autoimmune disorders, or malignancy [27].

Only 2 symptomatic PC retentions (4\%) were reported, but 1 patient (2\%) was admitted due to small-bowel obstruction, which was promptly resolved with conservative treatment and without further complications. Cases of symptomatic capsule retention have previously been reported with the PillCam PC $[7,8]$. In a retrospective analysis of 274 patients, Nemeth et al. [12] found symptomatic capsule retention in $1.8 \%$ of the patients. Also, recently, Rasmussen et al. [10] reported a bowel perforation due to PC retention, but this report had some limitations since the PC expiry date was exceeded. Other authors have also reported delayed PC disintegration times of up to 4 weeks after ingestion, which is much longer than intended [28]. In our previous report [29], we concluded that PC examination is a safe modality for securing small-bowel patency, with a very low frequency of symptomatic retention of $1.9 \%$ among 608 patients with CD or suspected CD. Only $0.3 \%$ of the patients were admitted for small-bowel obstruction following PC, which was successfully managed with corticosteroids.

All patients with confirmed small-bowel patency $(n=$ 49; 91\%) underwent CE, without incidents. In the 2 patients $(5 \%)$ in whom the capsule endoscope did not reach the cecum until the end of the recorder's battery life, the PCs were not detected at the 30-h evaluation and CE did not reveal any stricture until the end of battery life. A delayed small-bowel transit time may have been the reason for this finding.

\section{Conclusions}

This is one of the largest series evaluating gastrointestinal patency in CD patients, and it was performed in a single center, following the same PC protocol. The smallbowel PC retention rate of $9 \%$ in this prospective study was considerably lower than the rates previously reported. Our results show that, with this protocol, false-positive cases from RFIT scanning or plain abdominal X-ray may be avoided, since abdominal CT, with reduced radiation exposure, is useful for identifying capsule reten- 
tions in the colon caused by delayed bowel transit. This may contribute to more extensive application of CE without the risk of small-bowel retention. Utilization of RFIT scanners is justified, because they allow better selection of patients requiring CT. Also, in the future, we believe that the newly available LDCT - with reported radiation doses of around $0.62 \mathrm{mSv}$ [11], i.e., even lower than those from plain abdominal X-ray - could replace plain abdominal X-ray in patients in whom the PC was not excreted within the defined time frame.

\section{Statement of Ethics}

All patients gave previous written informed consent for the procedure, following adequate information regarding possible complications. The study was conducted in accordance with the ethical principles of the Declaration of Helsinki. The study was approved by the local ethics committee (Comissão de Ética para a Saúde do Centro Hospitalar São João/Faculdade de Medicina da Universidade do Porto). All rules of the local ethics committee were followed, preserving patient identity and confidentiality.

\section{Disclosure Statement}

The authors declare that they have no conflict of interest.

Funding Sources

The authors declare that there was no source of funding.

\section{Author Contributions}

Marco Silva: study design, data collection, and drafting of the manuscript; Hélder Cardoso: study design, performance of PC examinations, and revision of the manuscript; Rui Cunha: study design, performance of CT scans, and revision of the manuscript; Armando Peixoto: performance of PC examinations and drafting of the manuscript; Rui Gaspar: performance of PC examinations and drafting of the manuscript; Sara Gomes: drafting of the manuscript; Ana Luísa Santos: performance of PC examinations; Susana Lopes: critical revision of the manuscript; and Guilherme Macedo: critical revision and final approval of the manuscript.

\section{References}

1 Lai C, Zhou HC, Ma M, Zhang HX, Jia X. Comparison of magnetic resonance enterography, capsule endoscopy and gastrointestinal radiography of children with small bowel Crohn's disease. Exp Ther Med. 2013 Jul;6(1): $115-20$.

2 Ormeci AC, Akyuz F, Baran B, Gokturk S, Ormeci T, Pinarbasi B, et al. Retention during capsule endoscopy: is it a real problem in routine practice? J Int Med Res. 2016 Aug;44(4): 968-75.

3 Albuquerque A, Cardoso H, Marques M, Rodrigues S, Vilas-Boas F, Lopes S, et al. Predictive factors of small bowel patency in Crohn's disease patients. Rev Esp Enferm Dig. 2016 Feb;108(2):65-70.

4 Cheifetz AS, Kornbluth AA, Legnani P, Schmelkin I, Brown A, Lichtiger S, et al. The risk of retention of the capsule endoscope in patients with known or suspected Crohn's disease. Am J Gastroenterol. 2006 Oct; 101(10):2218-22.

5 Boivin ML, Lochs H, Voderholzer WA. Does passage of a patency capsule indicate smallbowel patency? A prospective clinical trial? Endoscopy. 2005 Sep;37(9):808-15.

6 Signorelli C, Rondonotti E, Villa F, Abbiati C, Beccari G, Avesani EC, et al. Use of the Given Patency System for the screening of patients at high risk for capsule retention. Dig Liver Dis. 2006 May;38(5):326-30.
7 Caunedo-Alvarez A, Romero-Vazquez J, Herrerias-Gutierrez JM. Patency and Agile capsules. World J Gastroenterol. 2008 Sep; 14(34):5269-73.

8 Römmele C, Brueckner J, Messmann $\mathrm{H}$, Gölder SK. Clinical Experience with the PillCam Patency Capsule prior to Video Capsule Endoscopy: A Real-World Experience. Gastroenterol Res Pract. 2016;2016:9657053.

9 Shirasawa T, Hashimoto S, Shimizu K, Kawasato R, Yokota T, Shibata H, et al. Effectiveness of using low-dose computed tomography to assess patency in gastrointestinal tracts with a patency capsule. Hepatogastroenterology. 2015 Jan-Feb;62(137):240-4.

10 Rasmussen B, Nathan T, Jensen MD. Symptomatic patency capsule retention in suspected Crohn's disease. J Crohn's Colitis. 2016 Dec;10(12):1445-7.

11 Annese V, Daperno M, Rutter MD, Amiot A, Bossuyt P, East J, et al.; European Crohn's and Colitis Organisation. European evidence based consensus for endoscopy in inflammatory bowel disease. J Crohn's Colitis. 2013 Dec;7(12):982-1018.

12 Nemeth A, Kopylov U, Koulaouzidis A, Wurm Johansson G, Thorlacius H, Amre D, et al. Use of patency capsule in patients with established Crohn's disease. Endoscopy. 2016 Apr;48(4):373-9.

13 Cave D, Legnani P, de Franchis R, Lewis BS; ICCE. ICCE consensus for capsule retention. Endoscopy. 2005 Oct;37(10):1065-7.
14 Yadav A, Heigh RI, Hara AK, Decker GA, Crowell MD, Gurudu SR, et al. Performance of the patency capsule compared with nonenteroclysis radiologic examinations in patients with known or suspected intestinal strictures. Gastrointest Endosc. 2011 Oct;74(4):834-9.

15 Herrerias JM, Leighton JA, Costamagna G, Infantolino A, Eliakim R, Fischer D, et al. Agile patency system eliminates risk of capsule retention in patients with known intestinal strictures who undergo capsule endoscopy. Gastrointest Endosc. 2008 May;67(6):902-9.

16 Cosnes J, Cattan S, Blain A, Beaugerie L, Carbonnel F, Parc R, et al. Long-term evolution of disease behavior of Crohn's disease. Inflamm Bowel Dis. 2002 Jul;8(4):244-50.

17 Postgate AJ, Burling D, Gupta A, Fitzpatrick A, Fraser C. Safety, reliability and limitations of the given patency capsule in patients at risk of capsule retention: a 3-year technical review. Dig Dis Sci. 2008 Oct;53(10):2732-8.

18 Spada C, Shah SK, Riccioni ME, Spera G, Marchese M, Iacopini F, et al. Video capsule endoscopy in patients with known or suspected small bowel stricture previously tested with the dissolving patency capsule. J Clin Gastroenterol. 2007 Jul;41(6):576-82.

19 Yamamoto H, Ogata H, Matsumoto T, Ohmiya N, Ohtsuka K, Watanabe K, et al. Clinical Practice Guideline for Enteroscopy. Dig Endosc. 2017 Jul;29(5):519-46. 
20 Dussault C, Gower-Rousseau C, Salleron J, Vernier-Massouille G, Branche J, Colombel JF, et al. Small bowel capsule endoscopy for management of Crohn's disease: a retrospective tertiary care centre experience. Dig Liver Dis. 2013 Jul;45(7):558-61.

21 Omori T, Nakamura S, Shiratori K. Localization of the Patency Capsule by Abdominal Tomosynthesis. Digestion. 2015;91(4):31825.

22 Koornstra JJ, Weersma RK. Agile patency system. Gastrointest Endosc. 2009 Mar;69(3 Pt 1):602-3.

23 Yoshimura T, Hirooka Y, Nakamura M, Watanabe O, Yamamura T, Matsushita M, et al. Clin- ical significance of gastrointestinal patency evaluation by using patency capsule in Crohn's disease. Nagoya J Med Sci. 2018 Feb;80(1):121-8.

24 Sawada T, Nakamura M, Watanabe O, Yamamura T, Ishikawa T, Furukawa K, et al. Clinical factors related to false-positive rates of $\mathrm{pa}$ tency capsule examination. Therap Adv Gastroenterol. 2017 Aug;10(8):589-98.

25 Mitselos IV, Katsanos K, Tsianos EV, Eliakim R, Christodoulou D. Clinical Use of Patency Capsule: A Comprehensive Review of the Literature. Inflamm Bowel Dis. 2018 Oct;24(11): 2339-47.

26 Jürgens M, Brand S, Laubender RP, Seiderer J, Glas J, Wetzke M, et al. The presence of fis- tulas and NOD2 homozygosity strongly predict intestinal stenosis in Crohn's disease independent of the IL23R genotype. J Gastroenterol. 2010 Jul;45(7):721-31.

27 Iskandar HN, Ciorba MA. Biomarkers in inflammatory bowel disease: current practices and recent advances. Transl Res. 2012 Apr; 159(4):313-25.

28 Garg S, Anand R, Dubin E, Kantsevoy S, Dutta $\mathrm{S}$. Endoscopic management of retained patency capsules. Endoscopy. 2014;46 Suppl 1 UCTN:E662-3.

29 Silva M, Cardoso H, Macedo G. Patency Capsule Safety in Crohn's Disease. J Crohn's Colitis. 2017 Oct;11(10):1288. 